\title{
PERANCANGAN APLIKASI GIS LOKASI PARIWISATA DI PULAU MOROTAI
}

\section{DESIGN APPLICATION (GIS) TOURISM LOCATION IN MOROTAI ISLANDS}

\author{
Arifandy Mario Mamonto ${ }^{1}$, Darman Umagapi ${ }^{2}$, Arisandy Ambarita $^{3}$ \\ ${ }^{1}$ Teknik Komputer, ${ }^{2,3}$ Manajemen Informatika \\ Politeknik Sains dan Teknologi Wiratama Maluku Utara \\ arifandymariomamonto@gmail.com
}

\begin{abstract}
Abstrak
Kabupaten Pulau Morotai memiliki potensi pariwisata dan termasuk dalam Kawasan Strategis Pariwisata Nasional. Penelitian ini bertujuan untuk merancang Sistem Aplikasi GIS penyebaran Objek Wisata Kabupaten Morotai. Metode pengumpulan data menggunakan Observasi dan Wawancara, Analisis system menggunakan Model Driven Berorientasi objek, sedangkan pengembangan system dan perancangan aplikasi menggunakan model prototyping. Dengan adanya Aplikasi GIS ini dapat memberikan petunjuk spasial secara global informasi sebaran objek wista pulau Morotai
\end{abstract}

Kata kunci: Aplikasi GIS, Objek wisata, Kawasan Strategis Pariwisata.

\section{Abstract}

Morotai Island Regency has tourism potential and is included in the National Tourism Strategic Area. This study aims to design a GIS Application System for the distribution of Morotai Regency Tourism Objects. Data collection methods using Observation and Interview, System analysis using the Object-Oriented Driven Model, while the system development and application design using prototyping models. With this GIS application, it can provide global spatial guidance on the distribution of information on the island of Morotai.

Keywords: GIS Applications, Tourism Objects, Tourism Strategic Areas.

\section{PENDAHULUAN}

Pengembangan sektor pariwisata menjadi sangat penting guna meningkatkan pendapatan nasional maupun pendapatan daerah dalam rangka meningkatkan kesejahteraan dan kemakmuran masyarakat, memperluas akses lapangan kerja dan mendorong pembangunan daerah. Hal ini menyebabkan banyak daerah berlomba-lomba memperkenalkan potensi pariwisata yang dimiliki agar dapat menarik kunjungan wisata sebanyakbanyaknya, baik wisatawan nusantara maupun mancanegara. Langkah pertama yang harus dilakukan terkait dengan pengembangan pariwisata adalah pemetaan kawasan strategis sebaran potensi pariwisata baik secara nasional maupun daerah.

Pulau Morotai merupakan kabupaten perbatasan yang terletak di ujung utara dari Indonesia bagian timur. Kabupaten ini terletak pada posisi $2^{\circ} 00^{\prime}$ Lintang Utara dan $2^{\circ} 40^{\prime}$ Lintang Utara, serta $128^{\circ} 15^{\prime}$ Bujur Timur dan $129^{\circ} 08^{\prime}$ Bujur Timur. Secara geografis, Pulau Morotai terletak di antara Samudra Pasifik dan Pulau Halmahera. Luas wilayah Pulau Morotai berupa daratan seluas $2.314,90 \mathrm{~km}^{2}$ 
Kabupaten Pulau Morotai memiliki banyak objek wisata yang tersebar di beberapa kecamatan di Pulau Morotai. Jumlah objek wisata sebanyak 31 lokasi, kecamatan Morotai Selatan sebanyak 21 objek wisata, kecamatan Morotai Timur sebanyak 3 objek wisata, kecamatan Morotai Selatan Barat sebanyak 2 objek wisata, kecamatan Morotai Utara 4 objek wisata, dan kecamatan Morotai Jaya sebanyak 1 objek wisata [1]. Berdasarkan analisis sementara mengenai pangsa pasar, diketahui bahwa pariwisata Pulau Morotai dapat diandalkan. Dimana pada tahun 2011, 2012 dan 2014 Pariwisata Pulau Morotai mengambil posisi terendah dari Sembilan daerah yang ada di wilayah Provinsi Maluku Utara. Namun pada tahun 2015 dan 2017, pariwisata Pulau Morotai meningkat pada posisi ke empat. Penelitian yang membuktikan potensi Pariwisata Morotai adalah Muharto et al (20170) [2] yang melakukan analisis indeks daya saing pariwisata, dimana pariwisata Morotai walapun terbilang sebagai daerah baru, namun berhasil menempati peringkat nomor 4 diantara 9 kabupaten/kota yang ada di Provinsi Maluku Utara. Namun permasalahan yang terjadi pada saat ini adalah tidak adanya pemetaan Kawasan strategis pariwisata yang dapat memberikan informasi bagi masyarakat dan pelaku bisnis untuk mengembangkan kegiatan pariwisata.

Pada Peraturan Pemerintah Republik Indonesia Nomor 50 Tahun 2011 tentang Rencana Induk Pembangunan Kepariwisataan Nasional Tahun 2010 2025 [3], Kawasan Strategis Pariwisata Nasional yang selanjutnya disingkat KSPN adalah kawasan yang memiliki fungsi utama pariwisata atau memiliki potensi untuk pengembangan pariwisata nasional yang mempunyai pengaruh penting dalam satu atau lebih aspek, seperti pertumbuhan ekonomi, sosial dan budaya, pemberdayaan sumber daya alam, daya dukung lingkungan hidup, serta pertahanan dan keamanan dan Pulau Morotai merupakan salah satu wilayah di provinsi maluku utara yang masuk dalam rencana pengembangan KSPN. Dalam hal ini, menjadi sangat penting melakukan penelitian perancangan aplikasi GIS penyebaran objek wisata Pulau morotai, Sistem Informasi Geografis (GIS) adalah suatu komponen yang terdiri dari perangkat keras, perangkat lunak, data geografis dan sumber daya manusia yang bekerja bersama secara efektif untuk memasukan, menyimpan, memperbaiki, memperbaharui, mengelola, memanipulasi, mengintegrasikan, menganalisa dan menampilkan data dalam suatu informasi berbasis geografis [4]. Penilitian ini bertujuan merancang Aplikasi GIS penyebaran Objek Wisata Kabupaten Morotai sebagai petunjuk spasial secara global informasi sebaran objek wista pulau Morotai

\section{LANDASAN TEORI}

\section{Sistem Informasi Geografis}

Georaphic information system adalah suatu sistem komputerisasi yang mempunyai kemampuan untuk membangun, mengelola, menganalisa, menyimpan dan menampilkan suatu informasi geografis dalam bentuk pemetaan dimana user yang membangun data serta mengoperasikannya juga termasuk dari bagian sistem tersebut [5]. Georaphic information system memiliki komponen yang terdiri dari manusia (orang), aplikasi, data, software dan hardware. Sedangkan berdasarkan tugasnya Georaphic information system memiliki tugas menginput, pembuatan 
data, manipulasi data, manajemen file, analisis query dan memvisualisasikan hasil

Georaphic information system diperkenalkan di Indonesia pada tahun 1972 dengan nama Data Banks for Development [6]. adanya georaphic information system seperti sekarang ini setelah dicetuskan oleh General Assembly dari International Geographical Union di Ottawa Kanada pada tahun 1967. Dikembangkan oleh Roger Tomlinson, kemudian dikenal dengan CGIS (Canadian GIS-SIG Kanada). CGIS digunakan untuk menyimpan, menganalisa dan mengolah data yang dikumpulkan untuk inventarisasi Tanah Kanada (CLI-Canadian Land Inventory) yang digunakan untuk mengetahui kemampuan lahan di wilayah pedesaan Kanada dengan memetakan berbagai informasi pada tanah, pertanian, pariwisata, alam bebas, unggas dan penggunaan tanah pada skala 1:250000. Sejak saat itu georaphic information system berkembang di beberapa negara termasuk di Indonesia pengembangan Georaphic information system dimulai di lingkungan pemerintahan dan militer. Perkembangan Georaphic information system menjadi pesat semenjak ditunjang oleh sumber daya yang bergerak di lingkungan akademik [7].

\section{Pariwisata}

Pariwisata merupakan sebuah kekayaan yang dimiliki oleh suatu wilayah yang dapat jadikan sebagai devisa serta icon tersendiri dan bagi masyarakat [8], daerah tujuan wisata yang selanjutnya disebut destinasi pariwisata adalah kawasan geografis yang spesifik berada dalam satu atau lebih wilayah administratif yang didalamnya terdapat kegiatan kepariwisataan dan dilengkapi dengan ketersediaan daya tarik wisata, fasilitas umum, fasilitas pariwisata, aksesibilitas, serta masyarakat yang saling terkait [9]

\section{Objek Wisata}

Objek wisata adalah kawasan geografi yang berada dalam satu atau lebih wilayah administratif yang di dalamnya terdapat daya tarik wisata, fasilitas umum, fasilitas pariwisata, aksesibilitas, serta masyarakat yang saling terkait dan melengkapi terwujudnya kepariwisataan [9]. Objek wisata terdiri dari objek wisata alam, objek wisata pantai, objek wisata kebudayaan, objek wisata acara tahunan dan lain sebagainya. Biasanya objek wisata sering dikunjungi karena keindahan pemandangan yang dimiliki objek wisata tersebut.

\section{Tujuan Pembangunan Kepariwisataan}

Peraturan Pemerintah Republik Indonesia Nomor 50 Tahun 2011 [10], Tujuan pembangunan kepariwisataan nasional adalah:

1. meningkatkan kualitas dan kuantitas Destinasi Pariwisata;

2. mengkomunikasikan Destinasi Pariwisata Indonesia dengan menggunakan media pemasaran secara efektif, efisien dan bertanggung jawab;

3. mewujudkan Industri Pariwisata yang mampu menggerakkan perekonomian nasional; dan

4. mengembangkan Kelembagaaan Kepariwisataan dan tata kelola pariwisata yang mampu mensinergikan Pembangunan Destinas

5. Pariwisata, Pemasaran Pariwisata, dan Industri Pariwisata secara profesional, efektif dan efisien.

\section{ArcGIS}

Perangkat lunak ArcGIS merupakan perangkat lunak SIG yang baru dari ESRI 
(Environmental Systems Research Institute), yang memungkinkan pengguna untuk memanfaatkan data dari berbagai format data. Dengan ArcGIS pengguna dapat memanfaatkan fungsi desktop maupun jaringan, selain itu juga pengguna bisa memakai fungsi pada level ArcView, ArcEditor, ArcInfo dengan fasilitas ArcMap, ArcCatalog dan Toolbox (Komputer, Wahana 2014). Materi yang disajikan adalah konsep SIG, pengetahuan peta, pengenalan dan pengoperasian ArcGIS, input data dan manajemen data spasial, pengoperasian Arc Catalog, komposisi atau tata letak peta dengan ArcMap, memanfaatkan perangkat lunak SIG ArcGIS $10 \mathrm{sp} 1$ untuk pengelolaan data spasial dan tabular serta untuk penyajian informasi peta.[11]

\section{GPS}

Salah satu perlengkapan modern untuk navigasi adalah Global Positioning Satelite / GPS adalah perangkat yang dapat mengetahui posisi koordinat bumi secara tepat yang dapat secara langsung menerima sinyal dari satelit. Perangkat GPS modern menggunakan peta sehingga merupakan perangkat modern dalam navigasi di darat, kapal di laut, sungai dan danau serta pesawat udara.[12]

\section{Google Maps API}

Google Maps Application Programming Interface (API) merupakan sebuah fitur yang disediakan oleh Google Maps untuk memudahkan pengguna dalam menggunakan Google Maps untuk situs di perusahaan Anda. Dengan menggunakan Google Maps API, Anda bisa menyimpan (embed) Google Maps di situs perusahaan Anda dan menentukan titik point tertentu dengan mudah. Peta Google Maps yang ditawarkan hadir dalam berbagai pilihan mulai dari tampilan 2 dimensi, satelit, hybrid, terrain, hingga bantuan arahan dalam berkendara. Google Maps API cocok digunakan di semua sektor industri dan semua ukuran bisnis perusahaan mulai dari startup, UMKM hingga bisnis berskala besar. Google Maps mampu menambahkan akurasi pada tampilan situs Anda dengan menampilkan data yang dapat membantu mencari potensi yang tepat bagi bisnis di perusahaan Anda. Dengan kata lain, Google Maps API berfokus pada perkembangan perusahaan Anda dengan memantau aset penting bagi bisnis Anda [13]

\section{METODE PENILITIAN}

\section{Metode Analisis dan Pengembangan Sistem}

1. Metode Analisis Sistem

Metode Analisis sistem yang digunakan dalam penelitian ini adalah model driven berorientasi Objek dimana system yang lama di indentifikasi masalah terlebih dahulu kemudian di analisa dan dibuatkan rancangan usulan sistem menggunakan alat bantu $U M L$ yaitu menggambar model usulan sistem dengan Diagram Activity

2. Metode Pengembangan Sistem

Dalam metode pengembangan peniltian in menggunakan model Prototyping yaitu proses iterative dalam pengembangan sistem dimana requirement diubah ke dalam sistem yang bekerja (working system) yang secara terus menerus diperbaiki melalui kerjasama antara user dan analis[15] 


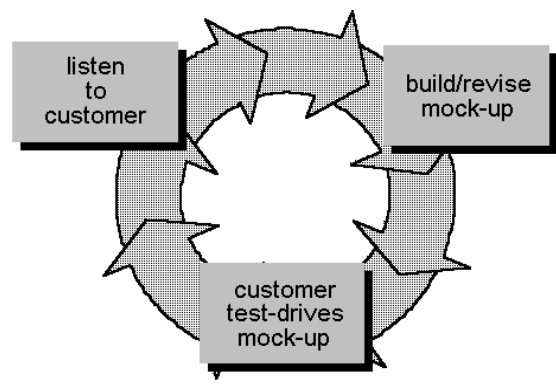

Gambar 1. Prototyping Model

Berikut merupakan urutan tahap model pengembangannya:

1. Tahap Pengumpulan Kebutuhan. pengembang dan user berasama melakukan observasi mengumpulkan data mendefinisikan kebutuhan sistem secara garis besar pada Kawasan Wisata diPulau Morotai

2. Tahap Quick design: membuat konsep rancangan sistem secara umum dengan Diagram UML (Activity Diagram) kemudian diberikan pada user dan pihak-pihak yang terlibat dalam pengembang

3. Tahap Pembangunan Prototype yaitu perancangan sistem membuat desain sistem menggunakan alat bantu diagram $U M L$, Rancangan Database dan Layout user interface, hasil prototyping sudah disetujui selanjutnya programmer melakukan Coding dan Digitasi pemetaan, pada Aplikasi ArcGis,

4. Tahap Evaluasi Pelanggan (User) setelah itu system dijalankan dan di uji coba menggunakan pendekatan model blackbox yang sudah dibuat sehingga pengembang dapat menganalisis kembali kebutuhan user atau pemakai

\section{Konsep Usulan Sistem GIS Penyebaran Objek Wisata}

Konsep Racangan Sistem merupakan rancangan usulan secara umum sistem untuk GIS penyebaran objek wisata pulau morotai, gambar tampilan rancangan usulan:

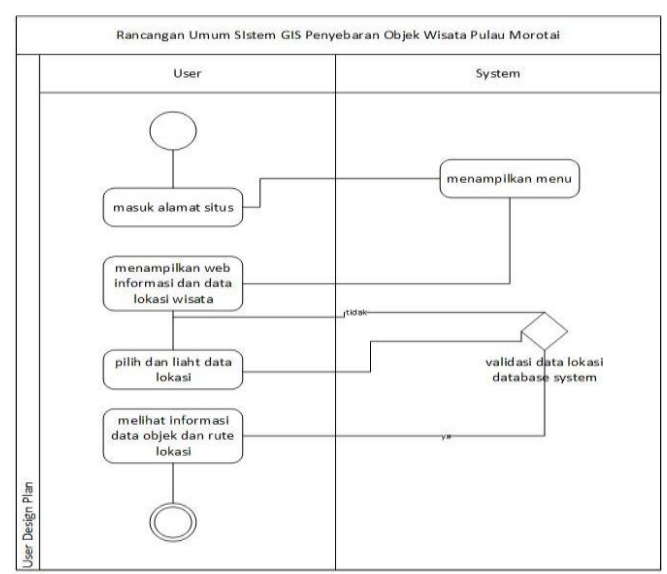

Gambar 2. Rancangan usulan GIS Penyebaran Objek Wisata

\section{PERANCANGAN SISTEM}

\section{Use Case Diagram}

Pada Use case diagram perancangan aplikasi GIS penyebran Objek Wisata Kabupaten Pulau Morotai terdiri atas Login, Kelola Lokasi, Kelola Kategori, Pencarian Lokasi dan Kelola admin, berikut merupaka tampilan gambar rancangan Use casenya

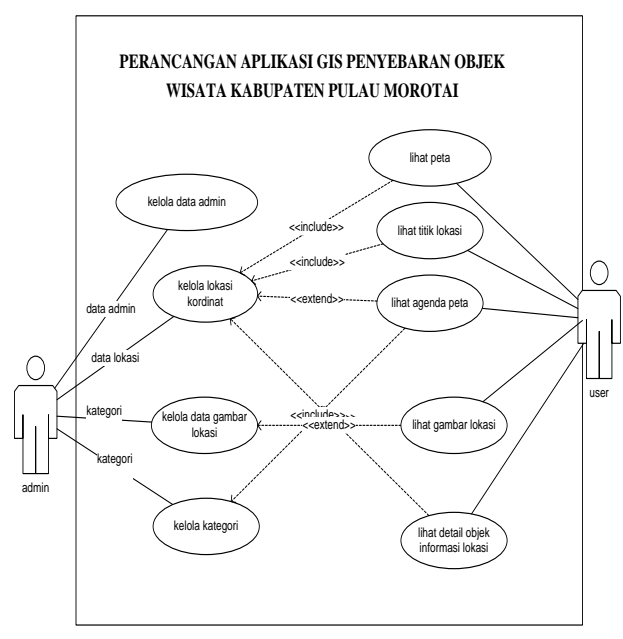

Gambar 3. Use case Diagram 


\section{Kebutuhan Fungsional}

Kebutuhan fungsional adalah tahapan yang menggambarkan fungsi-fungsi dari sistem yang akan dibangun. Tahapan ini akan dijelaskan pada tabel berikut dan akan digambarkan menggunakan activity diagram dan class diagram.

Tabel 1. Fungsional Sistem

\begin{tabular}{|c|c|c|}
\hline & \multicolumn{2}{|c|}{ Aktor } \\
\hline & Admin & User \\
\hline Dengelola lokasi & ya & \\
\hline DLengelola kategori & ya & \\
\hline DLelihat peta lokasi & ya & ya \\
\hline Melihat detail lokasi & ya & ya \\
\hline Melihat informasi & ya & ya \\
\hline Lengelola kategori. & ya & \\
\hline Melihat peta & & ya \\
\hline Selihat titik 1okasi & & ya \\
\hline
\end{tabular}

\section{Activity Diagram Admin}

Activity diagram admin login merupakan diagram rancangan uraian aktivfitas admin dalam melakukan login untuk dapat mengelola menu-menu yang lain, berikut rancangan Diagram activity admin

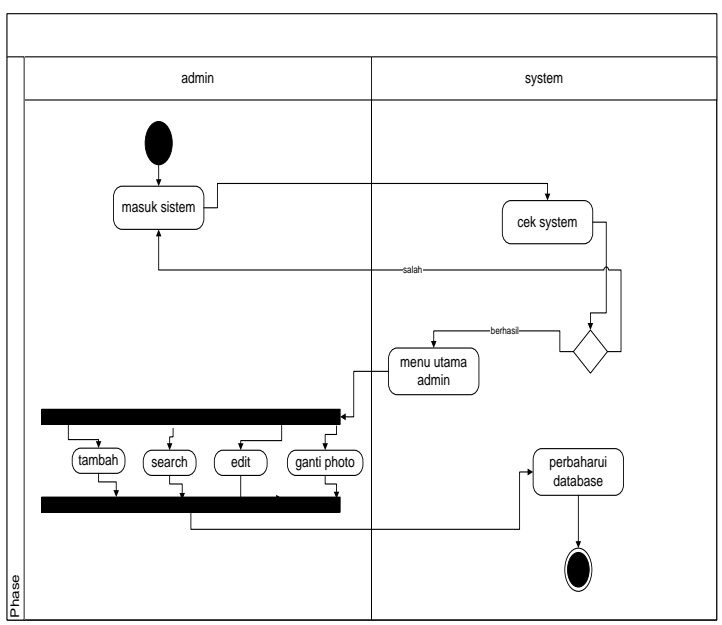

Gambar 4. Activity diagram admin

\section{Activity Diagram admin kelola Lokasi}

Activity diagram admin kelola admin merupakan rancangan diagram yang merupakan uraian fungsi admin diantaranya tambah, simpan edit dan hapus, berikut gambar rancngan diagram tersebut:

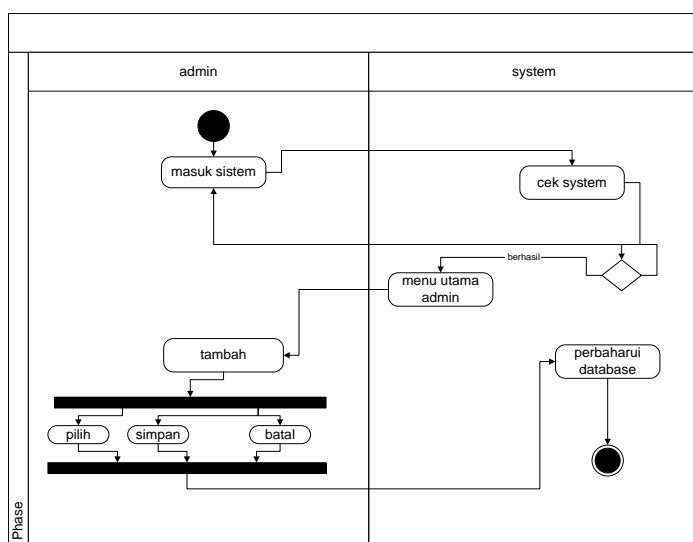

Gambar 5. Activity diagram kelola lokasi

\section{Activity user melihat peta}

Activity user melihat peta merupakan rancangan system user dalam melihat informasi pemetaan objek wisata yang ada pada system, berikut merupakan tampilan gamabr rancangan diagram activitynya:

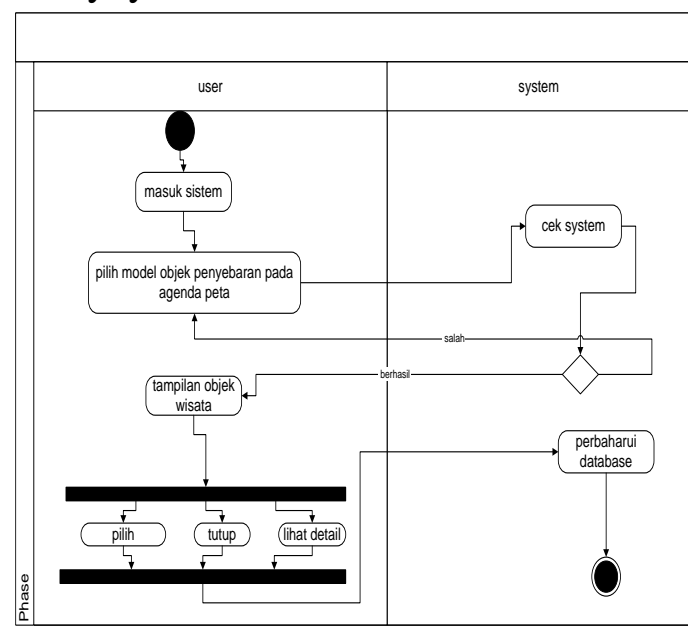

Gambar 6. Activity diagram kelola data kategori

Diagram Sequance Tampilan Admin 
Diagram sequance admin merupakan rancangan system admin mengelola sistem yang ada pada menu admin, berikut merupakan tampilan gambr rancangan diagram sequancenya:

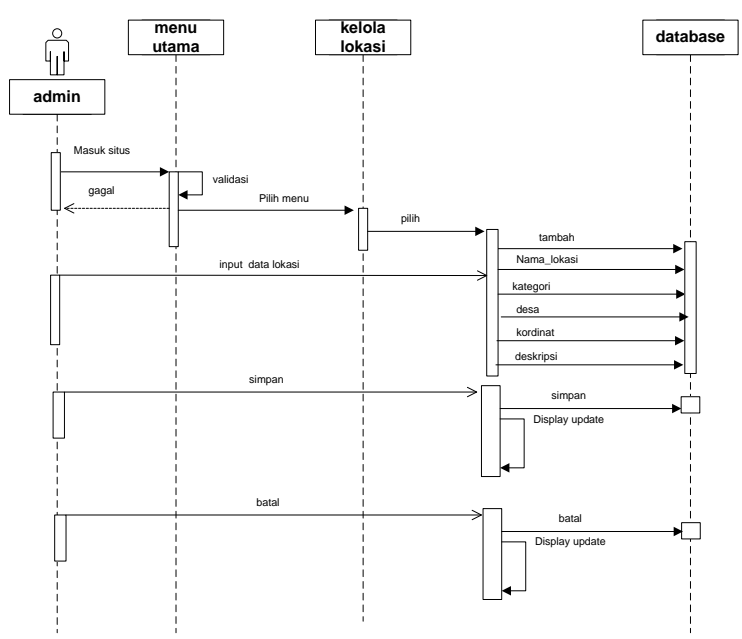

Gambar 6. Sequance diagram admin login

\section{Diagram Sequance user lihat peta}

Diagram sequance lihat peta merupakan rancangan system tampilan user mengakses peta yang ada pada system, berikut merupakan tampilan gambar rancangan diagram sequancenya:

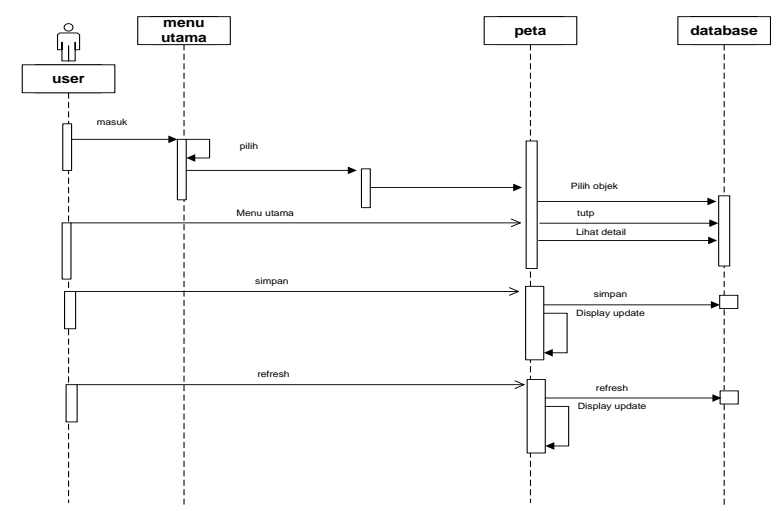

Gambar 7. Sequance diagram user melihat peta

\section{Tampilan Menu Admin}

Tampilan menu admin merupakan tampilan awal menu saat admin mengujungi website Sebaran Objek Wisata Di Pulau Morotai, berikut merupakan tampilan gambar menu awal admin

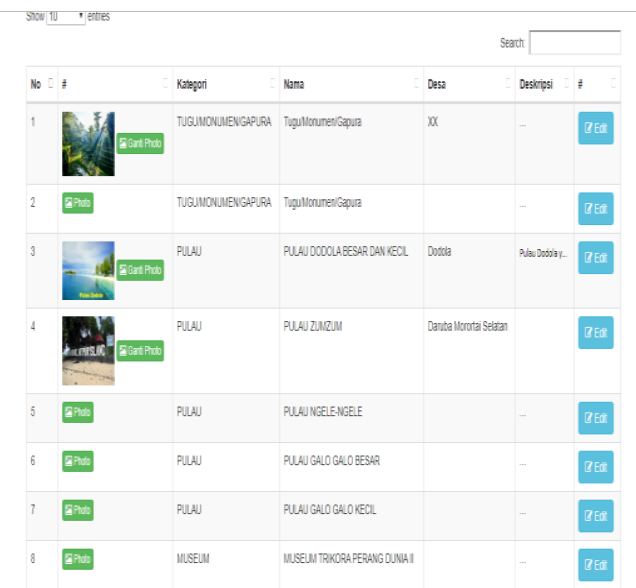

Gambar 8. Tampilan Menu Awal admin

\section{Menu Admin Tambah Lokasi}

Menu Admin Tambah Lokasi merupakan tampilan saat admin ingin menambahkan lokasi di sistem. Halaman ini berupa inputan dalam mengelola lokasi, kategori, kordinat deskripsi dan foto. berikut merupakan gambar menu tambah lokasi.

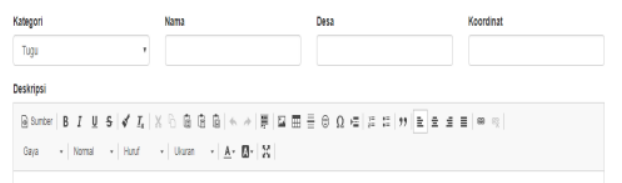

Gambar 9. Menu Awal admin tambah lokasi

\section{Tampilan Menu User}

Tampilan menu user merupakan tampilan awal menu saat user mengujungi website Sebaran Objek Wisata Di Pulau Morotai, berikut merupakan tampilan gambar menu awal user 


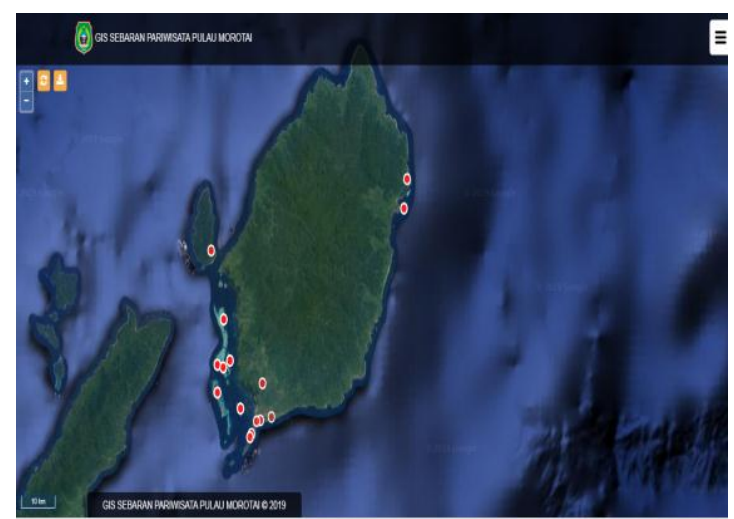

Gambar 10. Layout Menu Awal User

\section{Tampilan Menu User memilih objek lokasi}

Menu user memilih objek lokasi merupakan rancangan tampilan saat user ingin melihat dan memilih tempat lokasi peta di sistem. Halaman ini berupa tampilan peta dan agenda detail peta.berikut merupakan gambar menu user memilih objek lokasi

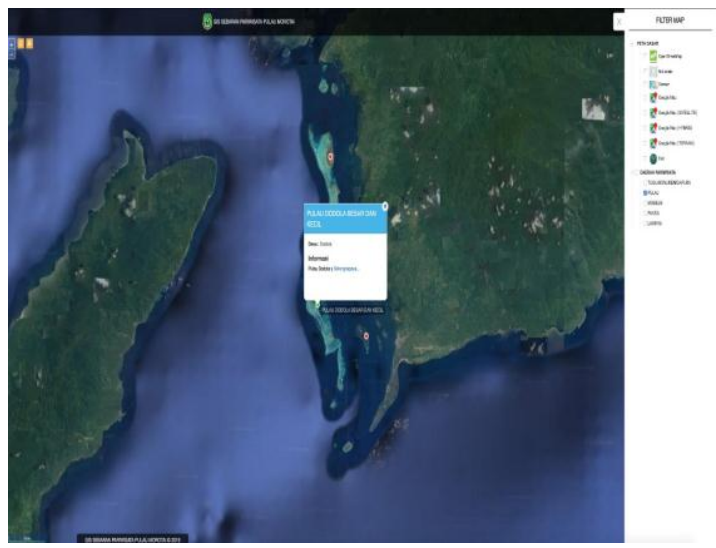

Gambar 11. Layout Menu User memilih objek lokasi

\section{Menu User melihat detail informasi objek lokasi}

Menu user melihat detail informasi objek lokasi merupakan rancangan tampilan saat user ingin melihat informasi lokasi secara detail. Halaman ini berupa tampilan infomasi detail objek lokasi peta dan agenda mode peta. berikut merupakan gambar menu user memilih objek lokasi

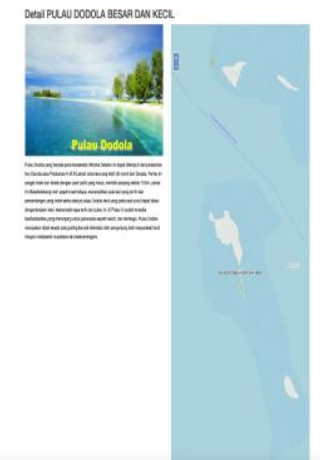

Gambar 12. Layout Menu User melihat detail informasi lokasi

\section{Pengujian Sistem}

Pengujian sistem merupakan tahap pada pengembangan sistem dimana sistem yang sudah di buat akan diuji berdasarkan fungsi dan kegunaan pada setiap menu dan database, pada penilitian ini peneliti menguji sistem menggunakan metode blackbox dimana metode ini hanya menguji fungsi dari setiap menu-menu pada sistem yang sudah dibuat, berikut merupakan table uji sistem blackbox

Tabel 2 Uji Sistem

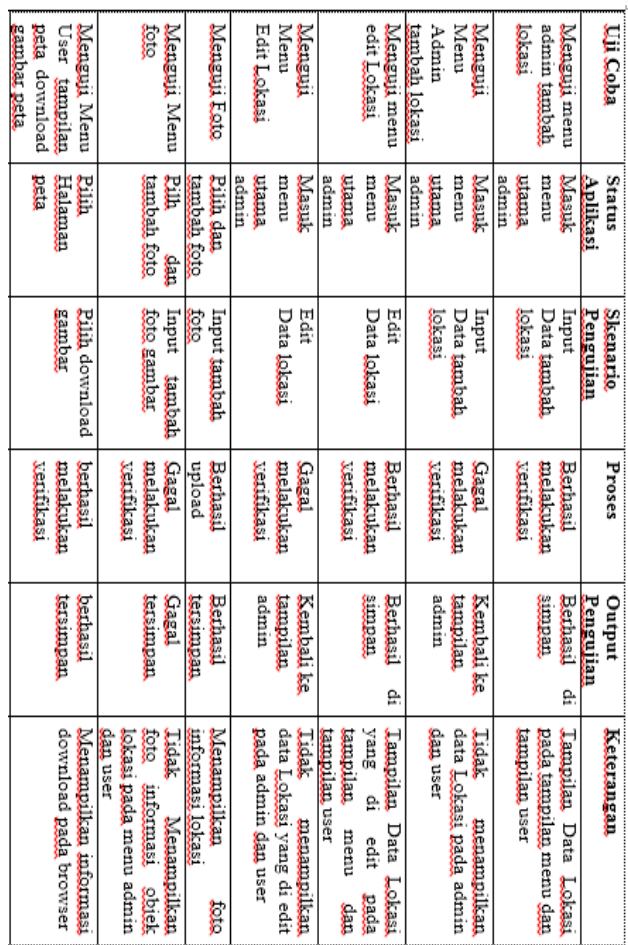


Tabel 3 Uji Sistem

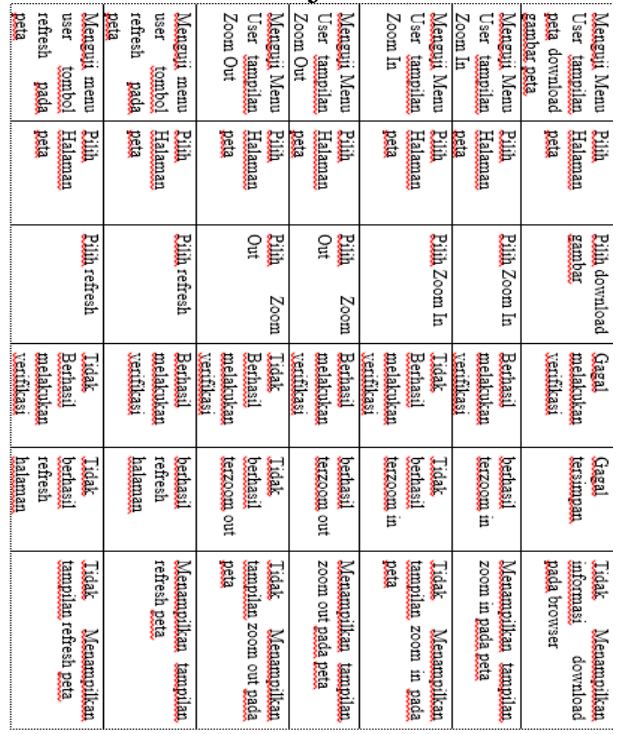

\section{KESIMPULAN}

Pegujian sistem menunjukan bahwa fungsi akses pada setiap menu-menu berjalan baik dan tidak eror data informasi yang di input dapat di proses oleh sistem dan menunjukan hasil luaran pada tampilan user dan di respon masingmasing komponen sistem, Dengan adanya Sistem ini dapat membantu pemerintah untuk mengelola informasi dan pengunjung dapat mengetahui spasial secara global informasi sebaran objek wisata pulau Morotai

\section{Saran}

Diharapkan agar pihak Pemerintah terutama instansi yang mengelola informasi lokasi objek wisata tersebut dapat menerapkan sistem ini secara online, Perlu adanya pengembangan system, terutama pada menu jarak tempuh dari setiap lokasi dan tampilan output yang mempunyai grafik objek wisata dan kunjungan sebelumnya.

\section{Ucapan Terima Kasih}

Terima kasih Kepada Kemenristek Dikti sebagai sponsor yang memberikan bantuan sumbangsi finansial pada Hibah penelitian Dosen Pemula Tahun 2019

\section{DAFTAR PUSTAKA}

[1] Kabupaten Pulau Morotai Dalam Angka, Tahun 2017, BPS Kabupaten Pulau Morotai, ISSN 2503-1317

[2] Muharto., B. Tewal., S. L Mandey, and A. Tumbel. 2017. Competitiveness And The Increasing Strategy of Competitiveness In Tourism Sector Of Ternate City, North Maluku Province. Interational Journal of Life Economics 4 (14) :11-32.

[3] Peraturan Pemerintah (PP) 50 tentang Rencana Induk Pembangunan Kepariwisataan Nasional Tahun 2010 2025 ,

https://peraturan.bpk.go.id/Home/Deta ils/5183/pp-no-50-tahun-2011

[4] Warnia Nengsih, GIS berbasis Web untuk Pemetaan Lahan menggunakan Classifier Model, Jurnal Komputer Terapan Vol. 2, No. 1, Mei 2016, pp 1-6, e- ISSN : 2460-5255 (Online) pISSN : 2443-4159 (Print)

[5] I. Mangatur, 2010. Sistem Informasi Geografis dan Penerapannya dalam Bidang HPT, Universitas Padjadjaran, Jatinangor,

[6] M.I. Ramadhan, 2013, Geographic Information System (Gis) In Education, Universitas Pendidikan Indonesia, Jakarta

[7] D. Oktafia, 2012. Sistem Informasi Geografis, Universitas Gunadarma, Depok

[8] Sugiama, A Gima. 2011. Ecotourism: Pengembangan Pariwisata berbasis konservasi alam. Bandung: Guardaya Intimarta.

[9] Undang-Undang No. 10 Tahun 2009 tentang Kepariwisataan. Jakarta : Menteri Hukum dan HAM. 2009. 
[10] Peraturan Pemerintah Republik Indonesia Nomor 50 Tahun 2011 tentang Rencana Induk Pembangunan Kepariwisataan Nasional Tahun 2010 - 2025

[11] Komputer, Wahana. 2014. Sistem Informasi Geografis Menggunakan ArcGIS: Panduan Dasar Bagi Mahasiswa Belajar Pemetaan Dengan ArcGIS. Elex Media Komputindo. Jakarta

[12] Bambang Eka Purnama, Pemanfaatan Global Positioning System Untuk Pelacakan Objek Bergerak, Journal Speed - Sentra Penelitian Engineering dan Edukasi - Volume 2 No 2 - 2009 ijns.org, ISSN : 1979-9330 (Print) 2088-0154 (Online)

[13]Pointstar, Google Maps Application Programming Interface (API), http://www.pointstar.co.id/googlemaps-api-indonesia/

[14] Sugiyono. 2013. Metode Penelitian Kuantitatif, Kualitatif dan $R \& D$. CV Alfabeta. Bandung

[15] Muharto \& Ambarita, A. 2016. Metode Penelitian Sistem Informasi: Mengatasi Kesulitan Mahasiswa Dalam Menyusun Proposal Penelitian. Deepublish. Yogyakarta. 